\title{
Piperacillin/tazobactam-induced myoclonic jerks in a man with chronic renal failure
}

\author{
Bik Ling Man, ${ }^{1}$ Yat Pang Fu ${ }^{2}$
}

'Department of Medicine and Geriatrics, Tuen Mun Hospital, Hong Kong, Hong Kong ${ }^{2}$ Department of Medicine, Tuen Mun Hospital, Hong Kong, Hong Kong

\section{Correspondence to} Dr Bik Ling Man, beli_man@yahoo.com

Accepted 17 April 2015
CrossMark

To cite: Man BL, Fu YP. BMJ Case Rep Published online: [please include Day Month Year] doi:10.1136/ bcr-2015-210184

\section{DESCRIPTION}

A 57-year-old man had microscopic polyangiitis with renal impairment. He was admitted for bronchiectasis and haemoptysis. PCR of Legionella pneumophila DNA was positive. The patient was given Piperacillin/tazobactam $2.25 \mathrm{~g}$ every $8 \mathrm{~h}$. He developed jerky movement of limbs after the second dose of the drug. Physical examination showed random myoclonic jerks of limbs (video 1) and tongue (video 2). The patient was alert and oriented. His limb power was full. Serum creatinine was $676 \mu \mathrm{mol} / \mathrm{L}$ (normal range 64-111), urea

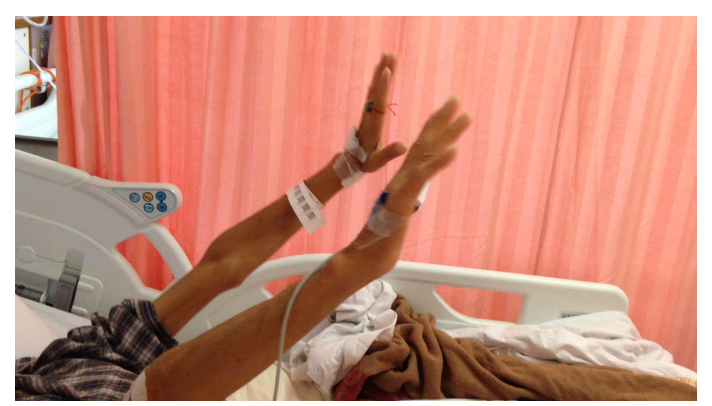

Video 1 Myoclonic jerks of limbs.

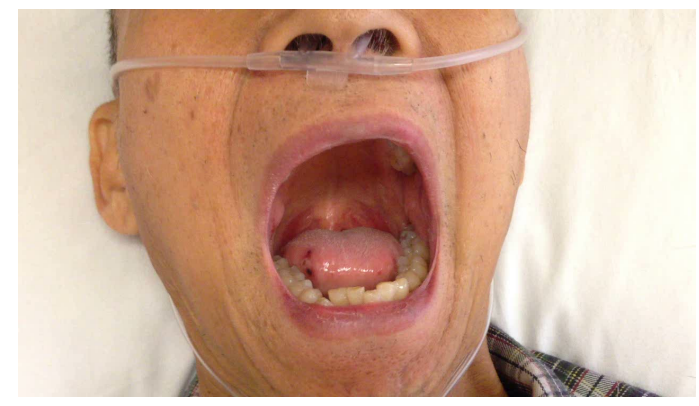

Video 2 Myoclonus of tongue.
$32 \mathrm{mmol} / \mathrm{L}$ (normal range 3-9.2). Serum potassium, calcium and magnesium were normal. CT of the brain and EEG were unremarkable. Piperacillin/ tazobactam was stopped and the myoclonus subsided.

Piperacillin/tazobactam-induced myoclonic jerks are rare. ${ }^{1}$ Piperacillin increases the risk of developing seizure activity by reducing inhibitory hyperpolarising chloride currents across $\gamma$-aminobutyric acid type A receptor-gated channels within the brain and spinal cord. ${ }^{1}$ Haemodialysis is useful in treatment of severe piperacillin-induced neurotoxicity. ${ }^{2}$

\section{Learning points}

- Piperacillin/tazobactam-induced myoclonic jerks are rare.

- Piperacillin increases the risk of developing seizure activity by reducing inhibitory hyperpolarising chloride currents across $\gamma$-aminobutyric acid type A receptor-gated channels within the brain and spinal cord.

- Haemodialysis is useful in treatment of severe piperacillin-induced neurotoxicity.

\section{Competing interests None declared.}

Patient consent Obtained.

Provenance and peer review Not commissioned; externally peer reviewed.

\section{REFERENCES}

1 Fernandez-Torre JL, Santos-Sanchez C, Pelayo AL, et al. De novo generalised non-convulsive status epilepticus triggered by piperacillin/tazobactam. Seizure 2010;19:529-30.

2 Lin CS, Cheng CJ, Chou CH, et al. Piperacillin/tazobactam-induced seizure rapidly reversed by high flux hemodialysis in a patient on peritoneal dialysis. Am J Med Sci 2007:333:181-4.

Copyright 2015 BMJ Publishing Group. All rights reserved. For permission to reuse any of this content visit http://group.bmj.com/group/rights-licensing/permissions.

BMJ Case Report Fellows may re-use this article for personal use and teaching without any further permission.

Become a Fellow of BMJ Case Reports today and you can:

- Submit as many cases as you like

- Enjoy fast sympathetic peer review and rapid publication of accepted articles

- Access all the published articles

- Re-use any of the published material for personal use and teaching without further permission

For information on Institutional Fellowships contact consortiasales@bmjgroup.com

Visit casereports.bmj.com for more articles like this and to become a Fellow 